\title{
Divergent GlocaliZATION In A Multinational ENTERPRISE
}

\author{
INSTITUTIONAL-BOUND STRATEGIC CHANGE IN EUROPEAN AND US SUBSIDIARIES
}

FACING THE LATE-2000 RECESSION

Mara Brumana and Giuseppe Delmestri ${ }^{1}$

\begin{abstract}
Glocalization, the blending of global and local cultural elements, has largely been interpreted as an in-between process, compromising between homogenous global standards and heterogeneous local traditions. Investigating strategic change in an MNE from 2005 to 2011, we found that glocalization can also unfold as a beyond process leading to divergent outcomes, outside the poles of an imagined local-global continuum. We studied the cognitive, political and institutional mechanisms that accounted for the process of blending strategies and structures before and during the late-2000 financial crisis and outlined a theory of institutional-bound strategic change within MNEs. We found sensegiving from the centre to be proactive during economic expansion and reactive during economic downturn. Following change initiation, sensegiving and sensemaking coalesced into a political iterative process of organizational identity work at subsidiary and HQ levels. We also found cognitive mechanisms were 'taken over' by political and institutional mechanisms: internally and externally demanded rationalization and the political prisms generated by multiple corporate governance traditions overshadowed the purely cognitive mechanism of sensemaking. Paradoxically, local societal-specific patterns of organization and strategy were preserved due to the actions of powerful central HQ-actors.
\end{abstract}

Keywords: strategic change, societal effect approach, new institutionalism, MNEs, proactive and reactive sensegiving, rationalization.

\footnotetext{
${ }^{1}$ Authors' names are listed alphabetically. The authors acknowledge their debt of gratitude to Arjen van Witteloostuijn for his editorial work. The manuscript benefited considerably from comments of two anonymous referees. The participants of the EGOS conferences 2010 and 2011, and the special issue workshop held at the University of Groningen in November 2010 provided insightful comments on earlier versions of the manuscript. We also wish to thank Florian Becker-Ritterspach, Arndt Sorge and Peter Walgenbach for their insightful comments on earlier versions of the paper.
} 


\section{INTRODUCTION}

Blending and combining diverse cultural and institutional elements has become widespread in global society (Robertson 1992; Scott 2001; Meyer 2002; Sorge 2005; Delmestri 2009). A new term, glocalization, has been created to describe this particular phenomenon (Robertson 1994, 1995). Glocalization processes are particularly pronounced in multinational enterprises (MNEs), social and economic entities characterized by multiple embeddedness and institutional plurality (Kostova 1999; Djelic and Sahlin-Andersson 2006; Quack 2007; Meyer, Mudambi, and Narula 2011). In MNEs, management practices and ideas are disseminated at a high pace leading to homogenization, translation, editing, and political contestation (Czarniawska and Joerges 1996; Sahlin-Andersson 1996; Clark and Geppert 2011). While the global dissemination of single HRM, accounting or production practices within MNEs has been widely investigated (i.e., Guler, Guillén and Macpherson 2002; Kostova and Roth 2002; Delmestri and Walgenbach 2009; Meyer and Höllerer 2010), the study of the transfer of comprehensive institutional arrangements and structures to define the whole organizational configuration and strategic posture of a subsidiary has been neglected. A possible reason could be the complexity of such an endeavour (Maurice 1979). Indeed, organizational structures and strategies present multifaceted affinities with national institutions and have highly specific characteristics, as the authors of the Societal Effect Approach (SEA), a European variant of institutional theory, have convincingly demonstrated (Maurice, Sellier and Silvestre 1977; Maurice, Sorge and Warner 1980; Sorge and Warner 1986; Sorge 1989, 1991; Maurice and Sorge 2000; see Rose 1985, and Delmestri 2002, for reviews). Such complexity has led researchers in all institutional traditions to concentrate on the diffusion and implementation of individual practices, disregarding the complex issue of learning, struggling with, and making sense of differences and similarities at the meso organizational level (Kostova, Roth and Dacin 2008; Greenwood and Miller 2010). 
Furthermore, prominent scholars within new institutionalism have recently made a plea to unpack, elaborate and explicate the "dependent variable", namely, the organization, up to now treated as a "black box" whose relationship with the institutional environment remained "unarticulated" (Suddaby, Elsbach, Greenwood, Meyer and Zilber 2010: 1238). In the context of MNEs, we contend that unpacking means addressing the two sided coin of structure: on one side, structural differentiation within each subsidiary firm, i.e., "a specific way of dividing an organization into separate organizational components, careers, occupations and jobs", on the other, cross-national coordination and control, i.e., all "the mechanisms instituted to tie the operations and decisions within and across components into a larger whole and establish coherence of meaning and purpose within the larger enterprise" (Harzing and Sorge 2003: 190).

Our research questions address these requests to unpack the organization and confront the meso-level complexity of structures and strategies: How does the glocalization process unfold when we open the black box of the organization and take into consideration both strategies and structures? What mechanisms are at the base of the observed strategic change? What outcomes can we expect in terms of stability, convergence or divergence in strategies and organizational structures?

To address these questions, we decided to study longitudinal processes of blending local and global structural elements in the subsidiaries and at the headquarter of an MNE brought about by a strategic change initiative pursued by the owner-manager. We concentrated on the glocalized blending of corporate and subsidiary strategies and organizational structures. Glocalization has been defined as a process noun "formed by telescoping global and local to make a blend" (The Oxford Dictionary of New Words 1991: 134, quoted in Robertson 1995: 28). Accordingly, the blending metaphor carries meanings of mixing local/global elements, adapting and adjusting global cultural material to the local context, and 'uploading' local elements into the global sphere. We found, instead, that glocalization could also result in heightened local or global characterization, 
i.e., in organizational structures and strategies diverging beyond the poles of the imagined continuum implied by the blending image. Paradoxically, and unlike the usual conceptions of such global-local relationships, central HQ-actors, namely the owner-manager and some of his fellow top managers and co-owners, defended the preservation of local cultural specificities in strategies and structures against pressures from local actors requesting the adoption of centrally governed standards.

We also observed that the mechanisms driving such change partly differed from those usually described in strategic change literature emphasizing managerial cognition (Gioia and Chittipeddi 1991; Dunford and Jones 2000). While the cognitive mechanisms of sensegiving and sensemaking where prominent in the initiation of the strategic change initiative, particularly while economic expansion persisted, the economic downturn gave rise to a situation where meaning was created predominantly by anchoring the discourse and actions to both the institutional pillars of the local societies in which the MNE was operating and to the global cultural process of rationalization, thus requiring both the preservation of local national practices and the adoption of universalized recipes for standardized and systematized structures, procedures and accounts (Erez and Drori 2009). Nationally regulated corporate governance structures changed from latent mechanisms overshadowed by the sensegiving initiative of the owner-manager during economic expansion into operative political mechanisms during the crisis. Sensegiving, from being proactive in driving the strategic change initiative became reactive to the institutional pressures for rationalization channelled by local corporate governance prisms. The owner-manager had to accommodate, at the same time, political pressures for localization, and demands for rationalized global structures.

From 2005 to 2011, we studied the strategic change initiative in the seven European and US subsidiary firms belonging to an Italian industrial holding company active in the special steel profiles industry. In 2008 and 2010, we also collected extensive data on organizational configurations as defined within the SEA. Overall, we studied the global-local adoption and the 
local-global uploading of structural elements, the shared and contested meanings of the strategic roles and organizational identities of the subsidiary firms and the holding company, and structural features of the organizational configurations. Moreover, we were able to trace the cognitive, political and institutional mechanisms at work in the process. As underlined by Yin (2003), a case study research strategy is particularly useful when the research questions are aimed at explaining "how" a certain phenomenon takes place, rather than highlighting causal relationships. In studying in-depth only one case of strategic change, our objective is not to test existing theories but to generate new theoretical insights. We lean, however, on three theoretical perspectives to support the development of our case study:

1. Comparative institutionalism: both the previously mentioned SEA, a process-oriented theory that considers firms as embedded in their societal environment, and Tylecote and Visintin's (2007) treatment of corporate governance types.

2. World polity institutionalism, defined by Drori (2008: 449) as the institutional theory of globalization assuming that "the world is the environment and the nation states, as well as MNCs and international organizations, are the organizations embedded in it".

3. The cognitive strategic change literature developed from Gioia and Chittipeddi's (1991) seminal article, see for instance Dunford and Jones (2000), Rouleau (2005), and Fiss and Zajac (2006).

In the following, we justify the selection of our case and illustrate how we proceeded with data collection and analysis. Thereafter, we present the mechanisms we found operating in the observable glocalization processes, and their outcomes. Finally, we outline a theory of institutionalbound strategic change in the context of MNEs.

\section{ThE STUDY: WHY THIS CASE?}


In order to answer our research questions on the processes, mechanisms and outcomes of glocalization within the particular institutional environment of MNEs, we decided to choose a case that would allow for rich theory building.

Calvi Holding S.r.l. is a company with controlling interests in various industrial businesses, operating mainly in the manufacturing field (metallurgical and mechanical). Our empirical analysis examined the headquarters and seven manufacturing firms located in France, Germany, Italy and the US, all active in the production of special steel profiles, a trade based on high capital investments, high (tacit) skills of workers and small batch production. The owner-manager envisioned Calvi Holding's organization as a network of firms that should retain their independence while developing synergies, whereas the role of the holding company should be that of steering and coordination, providing administrative assistance as well as financial and managerial services. With regard to its internal structure and history, the MNE stems from a strategic change effort with the following characteristics that are relevant for our research questions:

1. The MNE is the result of a merger and acquisition process, lasting from 1998 to 2008, of firms with a strong local heritage (see Table 1 for details of the firms).

2. The firms were previously competitors in a globalized market.

3. Each firm belongs to a country - France, Germany, Italy and the USA - with a distinctive "manufacturing logic" (Sorge 1991: 180), i.e., institutional characteristics related to education, careers and industrial relations fostering more or less industrial versus artisanal practices and identities (Maurice, Sorge and Warner 1980; Herrigel 1994; Delmestri 1998).

4. The four countries, following Tylecote and Visintin (2007), span all existing corporate governance types (shareholder capitalism for the USA, stakeholder capitalism for Germany, state-led capitalism for France, and family/state capitalism for Italy) that radically differ with regard to employee protection and involvement, and the number of stakeholders beyond shareholders, if any, that participate in control. 
5. The holding firm is Italian and most of the owners belong to an Italian extended family, a situation that implies a specific organizational logic (Gagliardi and Turner 1993).

The above characteristics create a situation of both high complexity in dealing with societal and cultural differences, and balanced power relationships between the subsidiary firms and the holding firm, which contribute to defining a non-coercive intraorganizational/corporate institutional field (Kostova et al. 2008; Delmestri and Walgenbach 2009). These conditions, which may be particular of MNEs in more peripheral countries, however offer interesting breeding ground for blending processes in all directions relevant for the study of glocalization.

We conducted several interviews with French, German, Italian and US managers and top managers in each study year, extensive interviews with over 60 managers in France, Germany and Italy in 2007, direct and participant observation (by both authors to different degrees), data collection on dimensions of organizational structures in 2008 and $2010^{2}$, and analysis of company documents $^{3}$. Our approach allowed us to inductively observe the emergence of the processes and mechanisms driving glocalization, as well as the relative outcomes, within the strategic change championed by the owner-manager. Finally, we double-checked our preliminary conclusions by making four presentations to the top and middle managers of the MNE. The owner-manager and one top manager also read and commented on the previous version of this article.

Insert Table 1 about here

\section{THE FINDINGS: STRATEGIES AND STRUCTURES BEFORE AND DURING THE CRISIS}

We report our findings by following as much as possible the processes that unfolded as we observed them, the mechanisms that generated them, and their outcomes. We "recorded" the story 
from 2005 to 2011. As a preface to the events reported below, we here outline what had taken place in the years prior to 2005 .

The story begins in the early nineties with Riccardo Chini - actual president and majority shareholder of Calvi Holding together with his sister - leaving the family firm Siderval S.p.A., a company specializing in the hot drawing steel industry, to work for Calvi S.p.A., a firm specialized in cold drawing. After having successfully restructured Calvi S.p.A. and gaining control in 1998 through a leveraged buy-out, Riccardo Chini first acquired the Italian competitor Sipa S.p.A. in 1999, and immediately afterwards took control of Cefival SA, the French competitor of Siderval S.p.A., the family firm he had left to join Calvi S.p.A. With the backing of a small international group, Riccardo Chini approached his cousins at Siderval S.p.A. and negotiated a merger where his family line would retain majority-voting rights. The merger under the newly constituted Calvi Holding S.r.l. created the preconditions for the additional acquisitions in Italy first, and in Germany and North America later on. Calvi Holding grew fast: from 400 employees and a turnover of around $€ 60$ million in 2005, to ten firms in France, Germany, Italy and the United States, around 2000 employees and a turnover of $€ 400$ million in 2008.

The strategic rationale behind most of the acquisitions envisioned by the owner-manager was the belief that efficient and creative manufacturing in the specialty steel industry is sustained by preserving and valorising the existing productive cultures historically developed in specific companies and regions. He further believed that the industrial groups owning the firms to be acquired (the German ThyssenKrupp, the French Vallourec, and the US Carpenter Technology Corp.), would not be able to fully exploit and foster such productive cultures due to their dominant corporate-managerial orientation towards short term results, purely quantitative measures of success and the lack of involvement of top management in the actual productive processes. Thus, Calvi Holding mainly acquired firms in trouble with the intent of making them profitable, preserving them within the company "network" as valuable productive resources. 
In the following we present the story from 2005 to 2011, organized around the mechanisms that we were able observe at work. Although the mechanisms identified operated simultaneously and overlapped, for the sake of simplicity we present them in sequence taking into account their first appearance. Table 2a summarizes our findings with regard to both the mechanisms at work during the glocalization processes, and the prevailing global and local contents of the outcomes of these processes in terms of both strategies and organizational structures (Table $2 b$ presents representative supporting empirical data of the discussed mechanisms). Anticipating some of the outcomes in a language established in extant literature, such glocalization mechanisms created a multidomestic organizational structure (Harzing and Sorge 2003; Bartlett and Ghoshal 1990), with a polycentric strategic mindset (Gupta and Govindarajan 2002) and a strategic mandate for all subsidiaries to act as strategic partners (Birkinshaw and Hood 1998). All observed outcomes were more far-reaching however than this summary might suggest.

Insert Table $2 \mathrm{a}$ and $2 \mathrm{~b}$ about here

\section{Mechanisms at work during economic expansion and their effects on strategies and structures}

Sensegiving. In the year 2005, Riccardo Chini started to use the word "network" to label what he had in mind with regard to the multinational company he was going to assemble through mergers and acquisitions. He publicly acknowledged having read about this concept in an article on neuronal networks in a scientific magazine. The meanings of the word projected by the president, and a few other top managers who immediately picked it up, where related to independence of (even competition among) the nodes, learning from each other, helping each other when needed, and being part of a common project. 
Outcomes. Sensegiving organized from the centre had the effect of legitimizing the local strategic independence of the subsidiary firms, whose managers felt free to choose the actual product range, set prices and compete with other network-firms in getting orders. Sensegiving from the centre, however, was also successful in pushing local subsidiaries to compare, coordinate and negotiate local strategies. The institution of a cross-subsidiary Marketing and Sales Steering Committee created a decisional situation for common strategizing. However, more than the Committee, it was the design of a common look at important trade fairs, requested by a few subsidiaries for the declared reason of saving money, that had significant and unintended effects: sitting on the same stand close to each other obliged the sales people and managers to provide the customers, and themselves, with a strategic meaning for this physical and symbolic closeness. This dual local and global blend however did not only apply to strategies. We recorded a rediscovery and reinvention of traditional organizational identities in the subsidiaries that at same time attempted to make these compatible with the identity of the holding company as a network. Interestingly, an important part of the glocalization we describe is that the relatively fuzzy and ambiguous term network was interpreted locally following local understanding. In some cases, the term network was interpreted bureaucratically as a common ground for rules and procedures to be established, in others as a community of equals in need of cooperating with each other, or as an international extension of the family logic governing the Italian firms and as an internal competitive market.

Sensemaking. The creation of an MNE through a merger created numerous sensemaking situations, because individuals needed at least retrospectively to make sense of what happened, resolving "issues of identity and reputation" (Weick 1995: 12). Committees, trade fairs, the annual Marketing and Sales Meetings, in which all top and middle managers of the subsidiaries and the holding company participated, were all occasions where encounters triggered sensemaking. 
Outcomes. This mechanism took place on both strategic and organizational issues. Direct comparison with "the others" enabled the emergence of localizing questions such as: What are our unique strengths? What risks does the acquisition carry for us? Why do we do what we do in the way we do it? Are our management practices unique and valuable? Globalizing questions also arose: What is the right level of product range overlap? What can we learn from the other subsidiaries? What practices can be transferred internationally? Sensemaking, interwoven with meanings drawn from locally and globally available logics, constituted the ground for the creation of local and international coalitions among participants and for the subsequent organizational identity work.

Rationalization (internal and external). According to Drori, Jang and Meyer (2006: 206) rationalization is "the explicit organization of clearly defined social entities and their roles, relationships, and activities around clear and general rules and toward clear and general purposes". Scientization, higher education and the professionalization of management through university education are considered the pillars that support the global culture of rationalized organizations. In our case, this mechanism had a strong influence in moulding glocalization. Especially the younger and university educated managers and external consultants requested clarification of a network structure perceived as rather messy. They saw the merger as an occasion to clearly define responsibilities over product lines, preferably in the form of a clear-cut multidivisional structure, and the rational pursuit of efficiency and synergies. Moreover, growing into an MNE was seen by the Italians of this group as an opportunity to get rid of, or dampen, the traditional unclear family ties that structured strategic and operative decision-making. In addition, independent sales agents also requested rationalization, as they could not figure out how to deal with representing firms belonging to the same group and, at the same time, competing with each other. 
Outcomes. Rationalization requests, framed as a way to impose homogenous and culturally insensitive procedures and structures, were resisted due to both the negative attitude of the main owner and other top managers, and the benefits seen by locals in preserving the strategic autonomy of the subsidiary firms. The pressure for rationalization, however, had effects on both the local and global side of strategies and structures. During the confrontation of the challenge posed by rationalization requests, local actors, supported by central figures in the holding company, redefined the local strategic posture of their units. Local autonomy to pursue strategic courses should be preserved, and this was deemed rational insofar as subsidiary firms concentrated on a product range and followed strategies supported by societal resources and institutions. This development is consistent with a neo-contingency framework informed by the societal effect perspective, i.e., the idea that organization forms and practices, professional work identities, industrial structures and firm strategies are interdependent: "Societal differences in organizing and generating human resources, and the pursuit of different business strategies, are reciprocally related" (Sorge 1991: 163). Indeed, the firms in the four countries 'discovered' their comparative strengths in the pursuit of strategies connected with local resources and institutions. Interestingly, the comparison between the German Hoesch Schwerter Profile GmbH and the French counterpart Cefival SA, recollects the results obtained by Sorge and Maurice (1993) with regard to a similar comparison of strategies and structures in the machine-tool industry. As in their case, the German firm we studied had a much broader product range, was bigger and placed greater emphasis on the combination of volume and quality than the French firm. The merger led to the intensification of the described differences. The arguments used by local and central managers to justify this divergent choice mirror the neo-contingent explanation of cross-country differences put forward by Sorge and Maurice (1993) in their machine-tool cases, highlighting the role of the education system, local industries and universities, and customers. The French-German comparison in Calvi Holding is also consistent with the more institutional argument in Sorge's (1991) treatment of the 
machine-tool case: the special steel profile trade, as one of the most artisanal parts of the steel industry, found better conditions in Germany - a country whose prevalent manufacturing logic sees the combination of industrial and artisanal aspects in medium sized firms geared towards the modernization of traditional businesses - than in France, whose prevalent logic is that of big managerialized high technology firms. It is plausible, therefore, to interpret with Sorge (1991) the financial difficulties encountered since before the crisis by the French Cefival SA because of its greater distance from the prevalent logic in its society, and to see the relative success of the German Hoesch Schwerter Profile GmbH ascribable to its proximity to the prevalent manufacturing logic of German society. If we add to this picture the two bigger Italian firms, Siderval S.p.A. and Calvi S.p.A., the merger into Calvi Holding S.r.l. was followed, also in this case, by largely divergent strategic choices. With regard to the cold drawing technology, Calvi S.p.A.'s field, no obvious changes in strategy could be observed: the firm continued to follow the same broad strategy, leaving smaller firms in the network the responsibility of very small batches and profiles. With regard to the overlap with the German counterpart, no specific decisions were taken, apart from the general philosophy of "healthy internal competition" (the owner). With regard to hot extrusion technology, strategic divergence and reduction of overlap were pursued: Siderval S.p.A. should concentrate on its ability to continuously improve processes and reduce costs in high volume production, Hoesch Schwerter Profile GmbH should concentrate on complex and bigger shapes, while Cefival SA on new materials and the nuclear and airspace application fields. In these diverging strategic choices, the global and local components of the blend are clearly recognizable. The local characteristics (societal resources and institutions) became more vivid thanks to crossnational comparison: network interaction allowed profiling local differences that became globally meaningful. The global side, instead, was visible in the constant negotiation of such local specializations, as well as in the theorization of the holding company as a global portfolio of 
complementary technologies - an emergent response to the pressures for rationalization coming from the management group.

A similar process was also observable in terms of the overall organizational structure of the MNE. On one side, the reasoning on strategies discussed above was conducted in parallel with the reasoning on local organizational strengths, which led to the reaffirmation of local organizational logics against rationalizing attempts perceived as unduly homogenizing. In parallel, local independence in the network was visible in the continuing practice of multiple offers to customers, as if subsidiary-firms were independent. However, being part of a common network, perceived as a legitimate transnational umbrella, led to conceiving these logics as mutually compatible. Moreover, although the formalization of a clear multi-divisional structure as requested by consultants was resisted, a kind of "informal" divisional structure emerged to coordinate related products and customer offers: the "hot" division, led by a French top manager, succeeded in creating a stronger integration of activities and informal rules of conduct with regard to customer offers, while the "cold" division, which was led by the Italian owner-manager himself, worked more according to a kind of competitive internal market.

Organizational identity work. The symbolic and practical actions of managers and employees in asserting a positive organizational identity have been widely studied in organization theory (i.e., Clegg, Rhodes and Kornberger 2007; Hatch and Schulz 2002; Elsbach and Kramer 1996). Organizational identity is defined as shared views of what is central, enduring, and distinctive about the firm (Dyer and Whetten 2006) and provides a frame of reference that guides strategic processes and decisions (Short, Payne, Brigham, Lumpkin and Broberg 2009). The identity-relevant actions of managers and employees, that can be labelled as organizational identity work, were directed either at preserving an independent identity for the subsidiary firm, or at redefining their activity as part of the broader organizational identity of the holding company. 
Organizational identity work is sensegiving from the periphery, a mix of positive and negative responses to the sensegiving attempts from the centre.

Outcomes. From a strategic point of view and consistently with the general networkidentity, each firm retained its pre-merger company name, while assuming the same font, colour, and adding a common graphical element symbolizing the holding company. Only Siderval S.p.A. resisted the homogenization of the colour and font, and thanks to the decentralized governance structure of the group, succeeded during a board meeting in retaining its own font and logo (accepting, however, the addition of the graphical element). From an organizational point of view, it is interesting to note that identity work also led to the reinforcement of global practices. Counterintuitively, by way of asserting their own local identities, subsidiary firms actively engaged in 'universalizing' local management practices applicable to the whole group, for instance in control, maintenance, or production - an attitude that cannot be interpreted as a simple retrenchment in 'the local'. Conversely, the adoption of own practices by other subsidiaries was seen as confirmation of own local identity.

On the local side, the blend produced by organization identity work has some surprising features. By the three pair-matching comparisons of production units ${ }^{2}$, we remarkably found that Maurice, Sorge and Warner's 30-year old results on the difference of organizational structures and configurations among German, French and British firms were confirmed - with the difference that we do not have a British but a US firm, and that we added Italy to the sample. Maurice and colleagues (1980: 59; confirmed, for Italy, by Delmestri 1998) found that "[o]rganizational processes of differentiation and integration consistently interact with processes of educating, training, recruiting, and promoting manpower, so that both develop within an institutional logic that is particular to a society, and bring about nationally different shapes of organization". The overall shapes of the organizational configurations disclosed by the cited studies (see Figure 1 for the categories used to classify the numerical aspect of organizational configurations) showed that 
German companies were less laterally and hierarchically differentiated due to the influence of societal institutions related to training, education and workers' representation. In the ItalianGerman comparison (Delmestri 1998), organizational structures and occupational roles were found to be even less differentiated than in Germany, drawing on the prevalent artisanal and family logics still present in the North Italian industry (the family partly assuming a functionally equivalent role to that of the German welfare state). Table 3 summarizes the organizational findings of the cited studies.

Insert Figure 1 and Table 3 about here

Figures 2 and 3 (designed on the basis of Figure 1), show our findings of the comparison of the hot extrusion units in France, Germany and Italy (the comparison of the bigger cold drawing units between Germany and Italy is qualitatively similar) and the cold drawing units in Italy and the USA (for more details on configurational data analysed following Maurice and colleagues 1980 and Sorge and Warner 1986, see Brumana and Delmestri 2011). Our findings with regard to France and Germany support the above-summarized studies: the relative number of workers as part of the total personnel is largest in Germany (around 75\% compared to 54\% in France). Conversely, staff employees form a more sizeable element in France (46\% compared to around 25\% in Germany), the same applies to clerical and commercial employees as well as to managers, whereas technical staff represents a significant exception: around $12 \%$ in Germany, $10 \%$ in France. Adding the Italian case to this picture, we can highlight its proximity to Germany with reference to employee distribution between workers and staff (the former around $73 \%$, the latter around $27 \%$ ). Italian organizations have an intermediate position when considering the number of supervision, clerical and commercial employees, while the relative number of managers is close to the result obtained for France; the share of technicians and engineers is the lowest among the three countries. The 
interpretation of the US figures, in comparison to the Italian, are very similar to Sorge and Warner's (1986) interpretation of their British figures as summarized in Table 3. The US organization presents a lower component of workers but higher supervision and administrative and technical staff components (for the few variations from the findings of Maurice, Sorge, Warner and Delmestri, and their interpretation, see Brumana and Delmestri 2011). Overall, these results show that the merger process did not lead to the homogenization of organizational configurations in the four countries; more than this, societal differences discovered several decades ago remain almost unchanged. This analysis of configurational data confirms the findings presented above: organizational identity work led to the preservation of societal specific organizational configurations.

Insert Figure 2 and 3 about here

\section{Mechanisms at work during the crisis and their effects on strategies and structures}

Before presenting the mechanism at work during the crisis, we consider it important to depict the group's dramatic situation: the 2009 consolidated financial statement recorded a severe reduction of turnover (around - 47\% compared to 2008) and very similar data were registered in the same period in each subsidiary firms' financial statement. Concerning the employment situation, we report in Table 1 variations in the number of employees between 2008 and 2010.

The crisis can be interpreted as a dramatic drop in environmental munificence (Castrogiovanni 1991). It is important to note, however, that Calvi Holding S.r.l. and all subsidiary firms survived the crisis and were on the verge of taking advantage of the economic recovery. Since the end of 2009, the principal lender has pressed the holding company into assistance by 
international consultants in order to prepare a new business plan, capable of sustaining the total financial debt restructuring of the group.

Below we discuss the mechanism at work to deal with the crisis in the context of the glocalization process in progress presented above.

Governance mechanisms and regulations. During economic expansion, potential conflicts and differences over the respective identities and structures could easily be accommodated. The crisis imposed clear-cut decisions on matters such as who was going to lose money or even a job, and these were taken according to a particular local/global blend, where the local assumed the leading role. When dramatic decisions have to be taken, then these questions become decisive: 'Who controls the firm?', 'What is the relationship between the owner and managers?', 'How decentralized is economic power to private interests?', 'Who are the owners of the firm?' and 'How self sufficient are economic actors?', i.e., questions whose answers define the specific national system of corporate governance (Tylecote and Visintin 2007) and the nature of the firm as an economic actor within a national business system (Whitley 1994). Typically, similar questions were raised and discussed during formal meetings (i.e., board meetings, management committees, work councils), existing mainly due to national regulations. In unipolar systems of corporate governance, such as family/state capitalism for Italy and shareholder capitalism for the US, only one actor has control of the firm, directly the individual or family owner, the state, or indirectly the managers as shareholder representatives. In bi-polar state-led capitalism, such as in France, private firms have "two masters, their owners and the state". Multipolar stakeholder systems of corporate governance, such as German capitalism, challenge the "supremacy of ownership" even more by including as additional "masters", among others, employees, bankers and local and regional governments (Tylecote and Visintin 2007: 82-83). Moreover, employee protection, as a dimension of corporate governance related to the question 'Who owns the firm?' is higher in countries such as Italy and 
France than in Germany and even less in the USA (Pagano and Volpin 2001). In the following, we present the outcomes of these processes.

Outcomes. Encompassing all four governance types of the existing capitalist systems described above, it is not surprising that the prevalent Italian top management team of the family holding company, used to direct control typical of private midsized firms in Italy (Tylecote and Visintin 2007), even if tempered by the ideology of the (family) network, had to experience institutional stickiness in implementing changes, and that these changes followed societal-specific trajectories rather than a coherent central plan. Also due to the multidomestic structure of the holding company, organized as a network of independent firms, each firm implemented change following a societal-specific pattern. In Italy and France, countries with strong employee protection and no co-determination, only state-regulated early retirement plans were implemented under the direct control of top management. In the USA, a country with no employee protection and no codetermination, the host country manager autonomously dismissed workers without any restrictions. In Germany, a coordinated market economy with moderate employee protection and codetermination, the local firm was supported by local banks to allocate redundant workers, over $30 \%$ of the workforce, to a temporary employment company financed by the regional state that, through a trust agreement, also took indirect control over the firm, reducing the owner-manager's discretion on local affairs. In this situation, the holding company, as last resort authority in the network, struggled in preserving strategic coherence (see also Kristensen and Zeitlin 2001). Interestingly, also with regard to the organizational configurations, the local component grew in importance leading to largely divergent outcomes. Comparing 2008 and 2010 (data not shown here due to space limitations), the main changes concern France (relative increase in the weight of technicians and relative decrease in the consistency of workers), in accordance with the societal-specific tendency described by Maurice et al. (1980). Italy and Germany present relative stable shares of personnel, apart from a slight convergence in the weight of production and maintenance workers. 
With regard to the Italy-US comparison, the overall stability of the Italian figures can be compared with the deepening societal characteristics of the US subsidiary firm, such as the reduction in the weight of the workers' share, the increase in the already relatively high share of managers, supervisors and technical staff employees. The global, in the glocalized blend, could only be anchored in the preservation of the network idea, an identity resource that nobody wanted to abandon.

Summarizing, we found the actual corporate governance processes took place in specific meetings (i.e., board meetings under different laws, management committees, work council meetings) that contributed to configure the intraorganizational field of the MNE. In a multinational company, these meetings have to accommodate participants from different countries but are structured according to national laws. As such, governance meetings appear as a meso level prism connecting the macro, societal institutions, and the micro, interests and actions of different stakeholders. In our case, the result was, on one side, the intensification of local differences through the empowerment of local stakeholders, on the other, the partial delocalization of local stakeholders who started to perceive more clearly the common belief of being connected to the whole MNE.

Rationalization (internal and external). The crisis also created a stage for the revival of the 'rationalization battle' discussed above. The difficult financial situation of the group led the previously loosely-coupled group of managers that espoused a more corporate approach to organizational affairs, namely, the application of rationalized standardization instead of the logic of the firm as a family network, to gain supporters and form into a more stable international alliance to influence local strategic decisions in a direction the owners did not welcome. Moreover, the leading bank in the group of lenders, an international bank, successfully pressed the owner-manager into employing an international consultant to rethink the organizational structure of the MNE. The Italian branch of the American consulting firm pushed for the adoption of the multidivisional form, 
separating strategic responsibility from operational control. The internal team of top managers confronting the consultant team expressed opposing preferences to suggestions for more centralized and standardized structures, some supporting the consultants' proposals, others almost boycotting them.

Outcomes. Overall, the rationalization struggle led to the following paradoxical glocalized effect with reference to both strategies and structures: the cultural specificity and autonomy of firms could be preserved thanks to the resistance of the centre to the introduction of more rationalized strategies and organizational structures, while the periphery succeeded in realizing layoffs of workers and middle managers that the centre wanted to stop to avoid knowledge and competence spill-outs. The multidivisional form on which the consultants and the company team finally agreed was a radically watered down version of the "genuine" multidivisional form, where strategic and operative responsibility remained with the owner-manager and his local allies. The centre and the periphery were not always synonymous for the global and the local, but these roles shifted according to the topic and the situation.

Sensegiving and sensemaking. Although in a more reactive mode, the owner-manager continued his sensegiving attempts, adapting the image of the network by adopting some meanings espoused by the rationalization discourse. In the 2009 Marketing \& Sales Meeting, the idea of the network became directly associated with a discourse on teamwork, as a need to hold together. In the same meeting one year later, the idea of leadership was added, as the perceived need for more direction in network activities, although leadership was framed as the actions of the empowered employees on the periphery taking responsibility and not as direction from the centre, as espoused by the rationalization alliance. In 2011, sensegiving became more critical. The conference in June 2011, where the new structure put forward by the American consultants was presented to the rest of the management team, turned out to be a bizarre event where the owner manager half-heartedly 
announced the new "abstract structure" (already radically watered down) while immediately restating the continued validity of the network idea and interpreting the divisional form in "neuronal" terms.

Outcomes. It is too early for us to evaluate the outcomes of the owner's renewed reactive sensegiving efforts during the conference. Sensemaking by the management team at the conference was characterized by uncertainty as to the meaning of the 'new' structure and the 'old' network. However, before the June 2011 conference, it was clear that maintaining independence and searching for opportunities for cooperation were two unavoidable necessities.

\section{DISCUSSION}

In this article we partly opened the black box of the organization and, concentrating on numerical configurations and subsidiary strategies, attempted to understand how these were influenced by societal institutions, the structure of the MNE and environmental munificence (pre and during the late-2000 financial crisis). We studied corporate and subsidiary strategies and addressed the two-sided coin of structure in MNEs: we analysed both structural differentiation within seven subsidiary firms and cross-national coordination and control of the headquarter activities during a major strategic change initiative that, through international M\&As, transformed a small Italian producer into the major world player in the special steel profile business.

Looking at structural differentiation of subsidiary firms, i.e., one side of the coin, we did not find "institutional freedom" - asserted by Kostova and colleagues (2008: 999) as the normal state for MNEs placed at the crossroads of all too many institutional environments - to be significant in our case. Our results show that glocalization is a relevant phenomenon and that local traditions and global standards change in the process, but they also show that such transformations are a clear outcome of path-dependent processes where societal and global institutions play a central role. Indeed, our results confirm, 30 years later, the original studies of Maurice et al. (1980) and 
Delmestri (1998), highlighting the lower job and functional differentiation typical of German and Italian organizations in comparison to the French, and the intermediate position of the AngloAmerican organization between the French and the German. The fact that all firms belonged to the same MNE - unlike the older studies where the units investigated belonged to different companies did not have a homogenizing effect. Common ownership put managers and employees of the different firms in contact with one another, pushing them to better define their own identities. As a result of such reciprocal negotiation of identities, structures and strategies, each firm became more focused, and this happened in directions compatible with the dominant societal trajectories in neocontingent terms (Sorge 1991). This trend of strengthening societal differences continued after the outbreak of the crisis and as a response to it. Comparing the data collected in 2010 with those collected in 2008, the international differences between the organizational configurations became greater. The French organization increased the weight of technical staff departments in comparison to the workers, and the US organization increased the proportion of supervisors, managers and technical staff on workers. Only the Italian and German units, which were the most similar before the crisis, experienced a slight convergence in the production and maintenance components.

Looking at cross-national coordination and control, i.e., the other side of the coin, we found that 'the local' and 'the global' are strictly interrelated and that each contributes to the construction of the other in unexpected ways. We found 'central' actors struggling to preserve local specificity, and 'local' actors supporting global agendas informed by rationalization. Overall, sensegiving, sensemaking and organizational identity work appear as central mechanisms in the global-local encounter, which we conceived as an instance of glocalization. The latter produced both the globalization of local practices, and intensified local identities. Local identities, however, were not the simple restatement of 'the local', but represented a rediscovery of traditions in the face of other foreign identities that the merger process had made salient. In addition, resource scarcity and the sense of drama created by the late-2000 financial crisis empowered the latent mechanism of local 
corporate governance traditions: local formal governance arrangements acted, on one side, as a kind of political and institutional prism in asserting the endurance of societal characteristics, on the other they put local stakeholder in direct contact with stakeholders in other countries. All in all, the processes we observed assumed a rather divergent character, but of a glocalized kind, i.e., divergence in directions that did not exist before, beyond the poles of the previous standards and traditions.

With regard to cognitive strategic change theory, sensemaking and sensegiving - confirming Gioia and Chittipeddi's (1991) interpretation - were critical mechanisms in the entire period. During economic expansion, sensegiving acted as a political mechanism, as an initial attempt to influence interpretations of key internal and external stakeholder, that is, sensegiving-for-others. Sensemaking, in reaction, acted as the cognitive mechanism of understanding, that is, sensemakingfor-self (Gioia and Chittipeddi 1991). Although the two processes were reiterated during the whole period, after the initial sensegiving-instigation from the side of the owner-manager, the interpretations and the meanings associated with such sensegiving-attempts were increasingly drawn from societal and globally available logics. Sensemaking was increasingly conducted according to logics that stakeholders drew either from their local national embeddedness or from globally available standards and discourses. Therefore, purely cognitive sensegiving and sensemaking were less crucial mechanisms in the period during the crisis, as understanding and influencing were mostly driven by institutional mechanisms such as globally anchored rationalization and nationally embedded governance systems. As a response, proactive sensegiving turned into a more reactive form.

These results are consistent with recent contributions to strategic change literature emphasizing the local institutional context in influencing framing and symbolic management (Rouleau 2005, Fiss and Zajac 2006). They also underscore, however, that mechanisms affecting strategic change are not only at the disposal of heroic managerial cognition and action but can also 
be rather automatic or politically driven processes of enactment of institutional scripts anchored at national or even world society levels (Drori, Jang and Meyer 2006). In metaphorical terms, governing an MNE is like steering a fleet in a sea populated by whirlpools: each vessel could be caught in a different one and the fleet may disband. National societal institutions and global cultural processes, such as rationalization, could potentially draw on the sensemaking efforts of different actors in the MNE, making it difficult to stay at the helm of purposeful sensegiving. Steering was made easier in our case by the use of the multivocal term "network", until the late 2000 recession storm scattered the fleet.

Reflecting on these findings, an outline of a theory of institutional-bound strategic change within MNEs seems to emerge (see Figure 4):

a. Sensegiving is the attempt to proactively give direction to a plan by shielding the meanings carried through a strategic change initiative from the centrifugal attraction of powerful institutionalized meanings available in the relevant social and economic environments in which the entrepreneur is acting.

b. Proactive sensegiving is facilitated by the use of multivocal concepts and appropriate cognitive and political mechanisms.

c. At times, and especially due to the occurrence of an economic crisis, sensemaking is inevitably caught by institutional attractors giving rise to a centrifugal process and rendering sensegiving a reactive endeavour.

d. Incorporating selective institutional meanings into a new centripetal sensegiving cycle is a way of resisting take-over by institutional mechanisms.

e. Strategic change, as the attempt to control, govern and maintain the coherence of the meanings associated with it, is therefore a cyclical process with centripetal instances led by proactive sensegiving and centrifugal instances spurred by politically and institutionally anchored sensemaking and sensegiving. 


\section{CONClusions}

Reflecting on the findings of a longitudinal case study of an MNE, we were able to sketch a theory of institutional-bound strategic change. We show that cognitive processes do not occur in a cultural vacuum, but that, conversely, institutional forces may have the strength to almost "vacuumclean" the meanings that managers and entrepreneurs try to give to their initiatives. The cyclical model of strategic change we propose opens up new avenues for research, linking the micro cognitive processes and the macro structural features in which they are embedded.

In addition, our study allows us to draw a few additional theoretical implications for institutional theory. Thirty years of neoliberal globalization and liberal Europeanization were not able to wash away the societal effects discovered by Maurice and colleagues (1980) and Delmestri (1998). The continuing relevance of the societal-effect approach may be due to the fact that it developed as an organizationally informed variant of institutionalism within its cross-national comparative branch (Tempel and Walgenbach 2007), much in line with the actual organizational and identity turn in new institutionalism. As Greenwood and colleagues lament in the "New directions?" section of their recent review of organizational institutionalism (2008: 29): "few studies treat the organization as the level of analysis (Ocasio 1994) or examine how the organization might be treated as an institutional context for understanding intraorganizational behaviour". For the SEA, intraorganizational behaviours and roles are connected to the organizational and strategic levels through structures and identities constructed in societal-specific ways. Integrating this kind of comparative institutionalism with organizational institutionalism may give us more leverage to understand actual global, national and local phenomena in organizations. 
Our study, furthermore, confirms the need to understand the institutional environment not as a simple measure of cultural distance (the typical approach of International Business studies), but as "a rich constellation of interdependent structures and systems" (Henisz and Swaminathan 2008: 539; see also Berry, Guillén and Zhou 2010; Jackson and Degg 2008; Pajunen 2008). Such understanding would require an increased interest in qualitative and longitudinal studies.

As to the limitations of our study, we investigated an Italian MNE in a traditional industry characterized by the importance of tacit skills. Studies using our approach should also be conducted in different industries where knowledge is more codified and more easily transferrable and in MNEs belonging to countries with different centrality within the capitalist system. As a matter of fact, since the headquarters are located in Italy, a country less central and prestigious in the capitalist world system (Smith and Meiksins 1995) and without a visible original elaboration of exportable management theories, the possibility to impose an Italian model abroad would be more difficult than for headquarters located in more central societies (Delmestri and Walgenbach 2009; Delmestri 2009). Studying, however, MNEs headquartered in different countries to the usual suspects, may help us to effectively advance international business studies.

Concerning future research, it may be interesting to fully explore the unfolded mechanism of increased characterization of the global/local components of the blend, the role of corporate governance as a prism through which global trends and local institutional logics are recombined, as well as the role of vaguely defined constructs, such as networks, in overcoming and managing the tensions between the local and the global. 


\section{NoTES}

2. We replicated Maurice, Sorge and Warner (1980) groundbreaking study on societal differences in organizing manufacturing units and we conducted three pair-matching comparisons of production units controlling the following variables: product, technology, size, location, and dependence (1. hot extrusion units in France, Germany and Italy; 2. bigger cold drawing units in Germany and Italy; 3. smaller cold drawing units in Italy and the US). In order to compare organizational structures, we subdivided the workforce of each subsidiary into six categories according to "personnel status" and following Maurice et al. (1980) and Sorge and Warner (1986). For more details on the analysis of configurational data see Brumana and Delmestri 2011.

3. Most of the interviews were recorded and transcribed. Top management meetings could not be recorded, but extensive notes were taken. Field notes were analyzed following Miles and Huberman (1984). The part of the study conducted in 2007, whose extensive results are not presented here, also involved colleagues from universities located in the host countries. We wish to thank David Courpasson, Gili Drori, Olivier Givet and Peter Walgenbach. 


\section{REFERENCES}

Bartlett, C., and S. Ghoshal (1990), "The multinational corporation as an interorganizational network." Academy of Management Review, 15: 603-625.

Berry, H., Guillén, M. F. and Zhou, N. (2010), “An Institutional Approach to Cross-National Distance”, Journal of International Business Studies, 41: 1460-1480.

Birkinshaw, J. M. and Hood, N. (1998), "Multinational subsidiary evolution: capability and charter change in foreign-owned subsidiary companies”. Academy of Management Review, 23: 773795.

Brumana, M., G. Delmestri (2011), “Societal Differences Redux. Comparing Organizational Structures in French, German, Italian and US Firms“. In S. Albertini, M. Bergami, A. D’Atri, M. De Marco, P. De Vita, M. Ferrara, C. Rossignoli, S. Salvemini (eds.): Generations and Re-generations of Organizational Processes. Conference Proceedings. XII Workshop of the Italian Researchers and Professors of Organization, Naples, June, ISBN 978-88-89677-21-6.

Castrogiovanni GJ. (1991), "Environmental munificence: a theoretical assessment". Academy of Management Review, 16/3: 542-565.

Clark, E. and Geppert, M. (2011), "Subsidiary integration as identity construction and institution building: a political sensemaking approach”. Journal of Management Studies, 48: 395-416.

Clegg, S., Rhodes, C. and Kornberger, M. (2007), "Desperately seeking legitimacy: organizational identity and emerging industries", Organization Studies, 28/4: 495-513.

Czarniawska, B. and Joerges, B. (1996), “Travel of ideas”, in Czarniawska, B. and Sevón, G. (eds.): Translating organizational change. Walter de Gruyter: 13-48.

Delmestri (2009), "Institutional Streams, Logics and Fields". Research in the Sociology of Organizations, 27: 99-128. 
Delmestri, G. (2002), Institutionen, Technik und Ökonomie. Eine organisationstheoretische Untersuchung des deutschen und italienischen Maschinenbaus, Verlag Rainer Hampp, Munich.

Delmestri, G. (1998), "Do all roads lead to Rome... or Berlin? The evolution of intra- and interorganizational routines in the machine building industry", Organization Studies, 19/4: 639665.

Delmestri, G. and Walgenbach, P. (2009), "Interference among Institutional Influences and Technical-Economic Conditions: The Adoption of the Assessment Center in French, German, Italian, UK and US International Firms". International Journal of Human Resource Management, 20/4: 885-911.

Djelic, M. L. and Sahlin-Andersson, K. (2006), Transnational Governance. Institutional Dynamics of Regulation, Cambridge: Cambridge University Press.

Drori, G. S. (2008), “Institutionalism and globalization studies”, In R. Greenwood, Ch. Oliver, K. Sahlin, and R. Suddaby (eds): The Sage handbook of organizational institutionalism, Los Angeles, London, New Delhi, Singapore: Sage Publications: 449-472.

Drori, G. S., Jang, Y. S. and Meyer, J. W. (2006), "Sources of rationalized governance: crossnational longitudinal analyses, 1985-2002”. Administrative Science Quarterly, 51: 205-229.

Dunford, R. and Jones, D. (2000), "Narrative in strategic change". Human Relations, 53: 12071226.

Dyer, W. G. and Whetten, D. A. (2006), "Family firms and social responsibility preliminary evidence from the S\&P 500", Entrepreneurship Theory and Practice, 30/6: 785-802.

Elsbach, K.D. and Kramer, R. M. (1996), “Members' Responses to Organizational Identity Threats: Encountering and Countering the Business Week Rankings". Administrative Science Quarterly, 41/3: 442-476. 
Erez, M. and Drori, G. S. (2009), "Global Culture and Organizational Processes", in Rabi S. Bhagat and Richard M. Steers (eds.): Handbook of Culture, Organizations, and Work, Cambridge University Press: 148-179.

Fiss, P. C. and Zajac, E. J. (2006), “The Symbolic Management of Strategic Change: Sensegiving via Framing and Decoupling", Academy of Management Journal, 49/6: 1173-1193.

Gagliardi, P., Turner, B. (1993), “Aspects of Italian Management”. In Hickson, D. (Hrsg.): Management in Western Europe. Society, Culture and Organization in Twelve Nations, Walter de Gruyter, Berlin - New York.

Gioia, D. A., Chittipeddi, K. (1991), "Sensemaking and Sensegiving in Strategic Change Initiation”. Strategic Management Journal, 12: 433-448.

Greenwood, R., Miller, D. (2010), "Tackling Design Anew: Getting Back to the Heart of Organizational Theory”, Academy of Management Perspectives, November: 78-88.

Greenwood, R., Oliver, C., Sahlin, K. and Suddaby, R. (2008), "Introduction” in Greenwood, R., Oliver, C., Sahlin, K. and Suddaby, R. (Eds.): The Sage Handbook of Organizational Institutionalism, Los Angeles, London, New Delhi, Singapore: Sage Publications: 1-46.

Guler, I., Guillén, M. and Macpherson, J. (2002), "Global competition, institutions, and the diffusion of organizational practices: The international spread of ISO 9000 quality certificates", Administrative Science Quarterly, 47: 207-232.

Gupta, A. K. and Govindarajan, V. (2002). "Cultivating a global mindset", Academy of Management Executive, 16: 116-26.

Harzing, A. and Sorge, A. (2003), "The Relative Impact of Country of Origin and Universal Contingencies on Internationalization Strategies and Corporate Control in Multinational Enterprises: Worldwide and European Perspectives”, Organization Studies, 24/2: 187-214.

Hatch, M. J., Schultz, M. (2002), “The Dynamics of Organizational Identity”. Human Relations, 55/8: 989-1018. 
Henisz, W. and Swaminathan, A. (2008), "Institutions and International Business", Journal of International Business Studies, 39: 537-539.

Herrigel, G.B. (1994), "Industry as a Form of Order: A comparison of the Historical Development of the Machine Tool Industry in the United States and Germany", in Hollingsworth, J.R./Schmitter, P.C./Streeck, W. (eds.): Governing Capitalist Economies. Performance and control of Economic Sectors, New York and Oxford, Oxford University Press: 97-125.

Jackson, G. and Deeg, R. (2008), “Comparing Capitalisms: Understanding Institutional Diversity and its Implications for International Business". Journal of International Business Studies, 39/4: 540-561.

Kostova, T. (1999), “Transnational transfer of strategic organizational practices: a contextual perspective", Academy of Management Review, 24: 308-324.

Kostova, T. and Roth, K. (2002), "Adoption of an Organizational Practice by Subsidiaries of Multinational Corporations: Institutional and Relational Effects", The Academy of Management Journal, 45/1: 215-233.

Kostova, T., Roth, K. and Dacin, M. (2008), "Institutional theory in the study of multinational corporations: a critique and new directions", Academy of Management Review, 33/4: 9941006.

Kristensen, P.H. and Zeitlin, J. (2001), “The making of a global firm: local pathways to multinational enterprise". In Morgan, G., Kristensen, P.H. and Whitley, R., editors: The multinational firm: organizing across institutional and national divides, Oxford: Oxford University Press: 172-95.

Maurice, M. (1979), "For a Study of the 'Societal Effect': Universality and Specificity in Organization Research" in Lammers, C.J., Hickson, D.J.: Organizations Alike and Unlike. International and Interinstitutional Studies in the Sociology of Organizations, London u.a., Routledge and Kegan Paul. SS.: 42-60. 
Maurice, M., Sellier, F. and Silvestre, J.J. (1977), Production de la hiérarchie dans l'entreprise: recherche d'un effet sociétal, Tome I-II. Laboratoire d'Economie et de Sociologie du Travail (CNRS), Aix-en-Provence.

Maurice, M. and Sorge, A. editors (2000), Embedding organizations. Societal analysis of actors, organizations and socio-economic context, Amsterdam and Philadelphia, PA: John Benjamins.

Maurice, M., Sorge, A. and Warner, M. (1980), "Societal differences in organizing manufacturing units: A comparison of France, West Germany and Great Britain”, Organization Studies, 1/1: $59-86$.

Meyer, J.W. (2002), "Globalization and the expansion and standardization of management", in Sahlin-Andersson, K. and Engwall, L. (eds.): The expansion of management knowledge, Stanford University Press: 33-44.

Meyer, R. E. and Höllerer, M. A. (2010), "Meaning structures in a contested issue field: A topographic map of shareholder value in Austria", Academy of Management Journal, 53/6: $1241-1262$.

Meyer, K. E., Mudambi, R. and Narula, R. (2011), "Multinational enterprises and local contexts: the opportunities and challenges of multiple embeddedness". Journal of Management Studies, 48: $235-252$.

Miles, M. B., and Huberman, A.M. (1984), Qualitative data analysis. A source book of new methods, Newbury Park: Sage.

Ocasio, W. (1994), "Political dynamics and the circulation of power: CEO succession in the U.S. industrial corporations, 1960-1990”, Administrative Science Quarterly, 39: 285-312.

Pagano, M. and Volpin, P. (2001), "The political economy of finance", Oxford Review of Economic Policy, 17/4: 502-519. 
Pajunen, K. (2008), “Institutions and Inflows of Foreign Direct Investment: a Fuzzy-set Analysis". Journal of International Business Studies, 39/4: 652-669.

Quack, S. (2007), “Legal Professionals and Transnational Law-making: A Case of Distributed Agency". Organization, 14/5: 643-666.

Robertson, R. (1995), “Glocalization: Time-space and Homogeneity-heterogeneity", in M. Featherstone et al (eds.): Global Modernities, London: Sage: 25-44.

Robertson, R. (1994), “Globalization and glocalization”, Journal of International Communication, 1: $33-52$.

Robertson, R. (1992), Globalization: Social Theory and Global Culture, London: Sage.

Rose, M. (1985), "Universalism, culturalism and the Aix group: promise and problems of a societal approach to economic institutions", European Sociological Review, 1/1: 65-83.

Rouleau, L. (2005), "Micro-Practices of Strategic Sensemaking and Sensegiving: How Middle Managers Interpret and Sell Change Every Day", Journal of Management Studies, 42/7: $1413-1441$.

Sahlin-Andersson, K. (1996), "Imitating by editing success: The construction of organizational fields”, In: Czarniawska, B. / Sevón, G. (eds.): Translating organizational change, Walter de Gruyter: 69-92.

Scott, W.R. (2001), Institutions and Organizations, (2nd ed.), London: Sage.

Short, J. C., Payne, G. T., Brigham, K. H., Lumpkin, G. T. and Broberg, J. C. (2009), "Family firms and entrepreneurial orientation in publicly traded firms A comparative analysis of the S\&P 500”, Family Business Review, 22: 9-24

Smith, C. and Meiksins, P. (1995), "System, society and dominance effects in cross-national organizational analysis". Work, Employment and Society, 9/2: 241-267.

Sorge, A. (2005), The global and the local: Understanding the dialectics of business systems, Oxford: Oxford University Press. 
Sorge, A. (1991), "Strategic fit and the societal effect: interpreting cross-national comparisons of technology, organization and human resources”, Organization Studies, 12/2: 161-190.

Sorge, A. (1989), “An Essay on Technical Change: Its Dimensions and Social and Strategic Context", Organisation Studies, 10/1: 23-44.

Sorge, A., and Maurice, M. (1993), "The Societal Effect in the Strategies of French and West German Machine-Tool Manufacturers", in Kogut, B. (ed.): Country Competitiveness. Technology and the Organizing of Work. New York u. Oxford: Oxford University Press.

Sorge, A. and Warner, M. (1986), Comparative factory organization. An Anglo-German comparison of management and manpower in manufacturing, UK: Aldershot.

Suddaby, R., Elsbach, K., Greenwood, R., Meyer, J. and Zilber, T. (2010), “Organizations and their institutional environments - Bringing meaning, values, and culture back in: Introduction to the special research forum", Academy of Management Journal, 53/6: 1234-1240.

Tempel, A. and Walgenbach, P. (2007), "Global standardization of organizational forms and management practices? What new institutionalism and the business-systems approach can learn from each other", Journal of Management Studies, 44/1: 1-24.

Tylecote, A. and Visintin, F. (2007), “A New Taxonomy of National Systems of Corporate Governance", in Engelstad, F. (ed.): Capitalisms Compared (Comparative Social Research, Volume 24), Emerald Group Publishing Limited: 71-122.

Weick, K. E. (1995), Sensemaking in organizations, Thousand Oaks, London \& New Delhi, Sage Publication.

Whitley R. (1994), "Dominant Forms of Economic Organization in Market Economies", Organization Studies, 15/2: 153-182.

Yin R.K. (2003), Case Study Research. Design and Methods, SAGE Publications, Thousand Oaks. 


\begin{tabular}{|c|c|c|c|c|c|c|}
\hline \multirow[t]{2}{*}{ COMPANY } & \multirow[t]{2}{*}{ PRODUCT } & \multirow[t]{2}{*}{ TECHNOLOGY } & \multicolumn{2}{|c|}{$\begin{array}{l}\text { SIZE }\left(\mathbf{N}^{\circ} \text { of }\right. \\
\text { employees })\end{array}$} & \multirow[t]{2}{*}{ LOCATION } & \multirow[t]{2}{*}{ HISTORY } \\
\hline & & & 2008 & 2010 & & \\
\hline CALVI S.p.A. & $\begin{array}{l}\text { Special steel } \\
\text { profile }\end{array}$ & Cold drawn & 182 & 173 & $\begin{array}{l}\text { Merate (LC) } \\
\text { Italy }\end{array}$ & $\begin{array}{l}\text { Founded } 1950 \\
\text { Acquired } 1998\end{array}$ \\
\hline SIPA S.p.A. & $\begin{array}{l}\text { Special steel } \\
\text { profile }\end{array}$ & Cold drawn & 30 & ND & $\begin{array}{c}\text { Carnate (MB) } \\
\text { Italy }\end{array}$ & $\begin{array}{l}\text { Founded } 1981 \\
\text { Acquired } 1999\end{array}$ \\
\hline CEFIVAL SA & $\begin{array}{l}\text { Special steel } \\
\text { profile }\end{array}$ & Hot extruded & 80 & 77 & $\begin{array}{l}\text { Persan } \\
\text { France }\end{array}$ & $\begin{array}{l}\text { Founded } 1905 \\
\text { Acquired } 1999\end{array}$ \\
\hline $\begin{array}{l}\text { FIAV L. } \\
\text { MAZZACCHERA } \\
\text { S.p.A. }\end{array}$ & $\begin{array}{l}\text { Special steel } \\
\text { profile }\end{array}$ & Cold drawn & 62 & 62 & $\begin{array}{c}\text { Agrate Brianza } \\
\text { (MB) } \\
\text { Italy }\end{array}$ & $\begin{array}{l}\text { Founded } 1913 \\
\text { Acquired } 2000\end{array}$ \\
\hline SIDERVAL S.p.A. & $\begin{array}{l}\text { Special steel } \\
\text { profile }\end{array}$ & Hot extruded & 122 & 109 & $\begin{array}{c}\text { Talamona (SO) } \\
\text { Italy }\end{array}$ & $\begin{array}{c}\text { Founded } 1950 \\
\text { Merged } 2001\end{array}$ \\
\hline HSP GmbH & $\begin{array}{l}\text { Special steel } \\
\text { profile }\end{array}$ & $\begin{array}{l}\text { Cold drawn } \\
\text { Hot extruded } \\
\text { Hot rolled }\end{array}$ & 700 & 509 & $\begin{array}{l}\text { Schwerte } \\
\text { Germany }\end{array}$ & $\begin{array}{l}\text { Founded } 1868 \\
\text { Acquired } 2005\end{array}$ \\
\hline $\begin{array}{l}\text { RATHBONE } \\
\text { PRECISION } \\
\text { METALS, Inc. }\end{array}$ & $\begin{array}{l}\text { Special steel } \\
\text { profile }\end{array}$ & Cold drawn & 57 & 44 & $\begin{array}{l}\text { Palmer, MA } \\
\text { (USA) }\end{array}$ & $\begin{array}{l}\text { Founded } 1905 \\
\text { Acquired } 2008\end{array}$ \\
\hline
\end{tabular}

Table 1: The investigated firms

Tables $2 \mathrm{a}$ and $2 \mathrm{~b}$ : [see the end of the file]

\begin{tabular}{|l|c|c|c|}
\hline & Low & Medium & High \\
\hline Tallness of hierarchy & Italy; Germany & Great Britain & France \\
\hline Functional differentiation & Italy; Germany & Great Britain & France \\
\hline Share of staff employees as part of total workforce & Italy; Germany & Great Britain & France \\
\hline Supervision/workers & Germany; Italy & Great Britain & France \\
\hline Administrative and commercial personnel/workers & Germany & Italy; Great Britain & France \\
\hline Technical personnel/workers & Italy; Germany & Great Britain & France \\
\hline Authority positions/workers & Great Britain & Germany; Italy & Germany; Italy \\
\hline Authority positions/staff & Great Britain & France & \\
\hline
\end{tabular}

Table 3: Structural specialization and differentiation in Italy, Germany, Great Britain and France. Source: Maurice et al. (1980), Sorge and Warner (1986), Delmestri (1998, 2002) 


\begin{tabular}{|c|c|c|}
\hline & $\begin{array}{c}6 \\
\text { Managers }\end{array}$ & \\
\hline $\begin{array}{c}\mathbf{4} \\
\begin{array}{c}\text { Technicians, engineers } \\
\text { (senior/junior) }\end{array}\end{array}$ & $\begin{array}{c}\mathbf{3} \\
\text { Supervision }\end{array}$ & $\begin{array}{c}\mathbf{5} \\
\text { Clerical, administrative, } \\
\text { commercial employees } \\
\quad \text { (senior/junior) }\end{array}$ \\
\hline \multicolumn{2}{|c|}{$\begin{array}{c}1 \\
\text { Production workers }\end{array}$} & $\begin{array}{c}\mathbf{2} \\
\text { Maintenance workers, } \\
\text { toolmakers }\end{array}$ \\
\hline
\end{tabular}

Fig. 1: Workforce categories in configurations. Source: Maurice et al. (1980: 64)

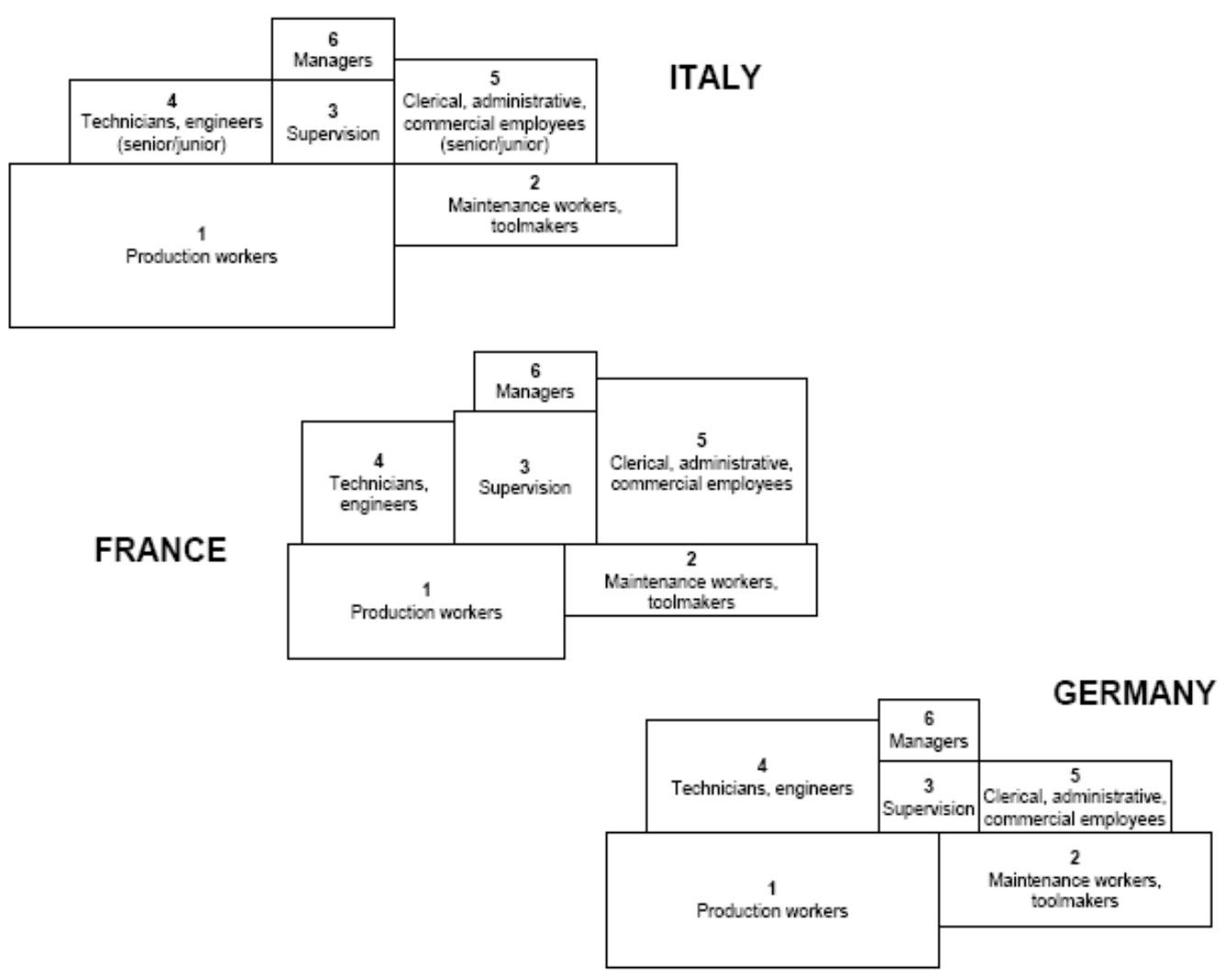

Fig. 2: Workforce categories in Italy, France and Germany (2008) 

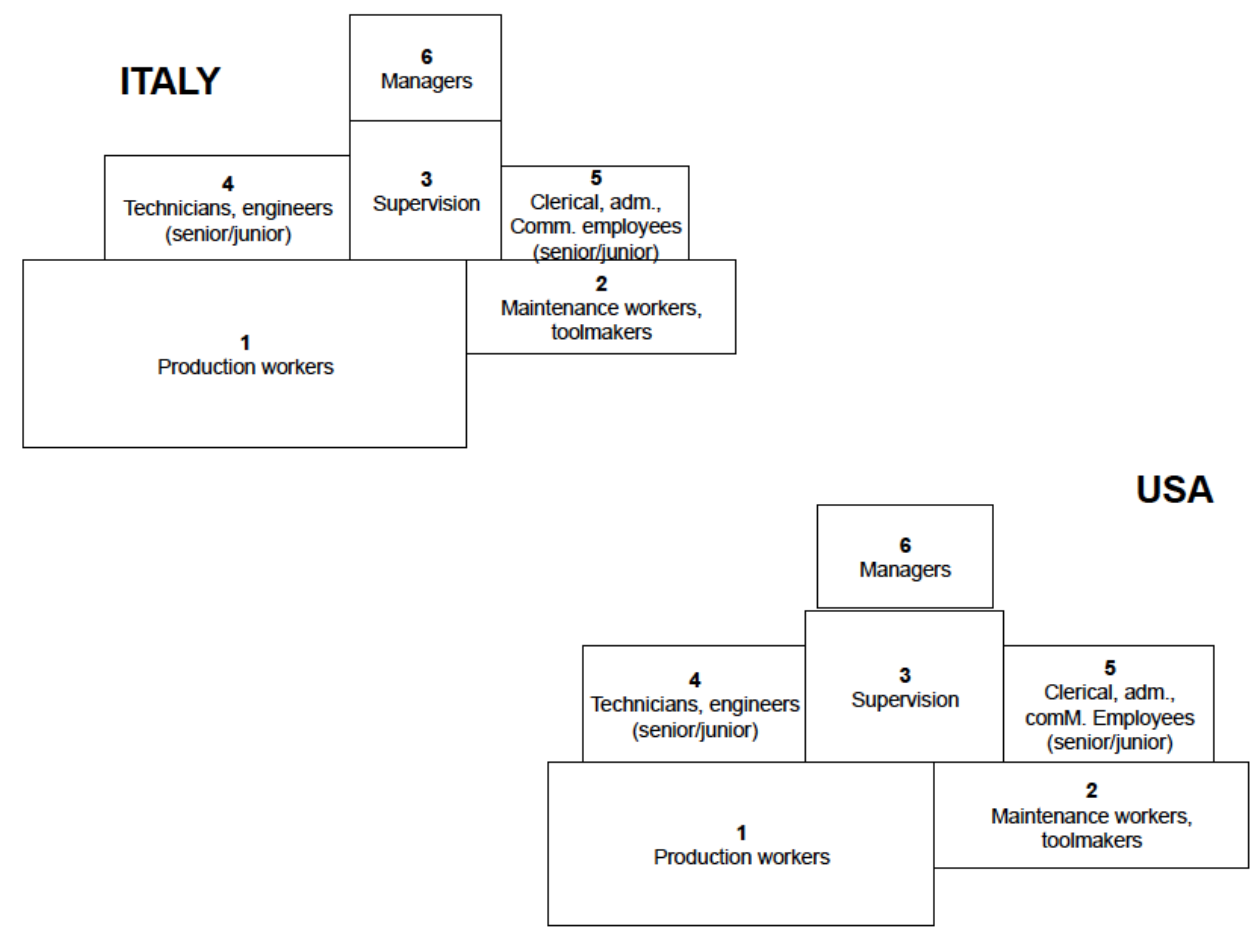

Fig. 3: Workforce categories in Italy and the US (2008) 


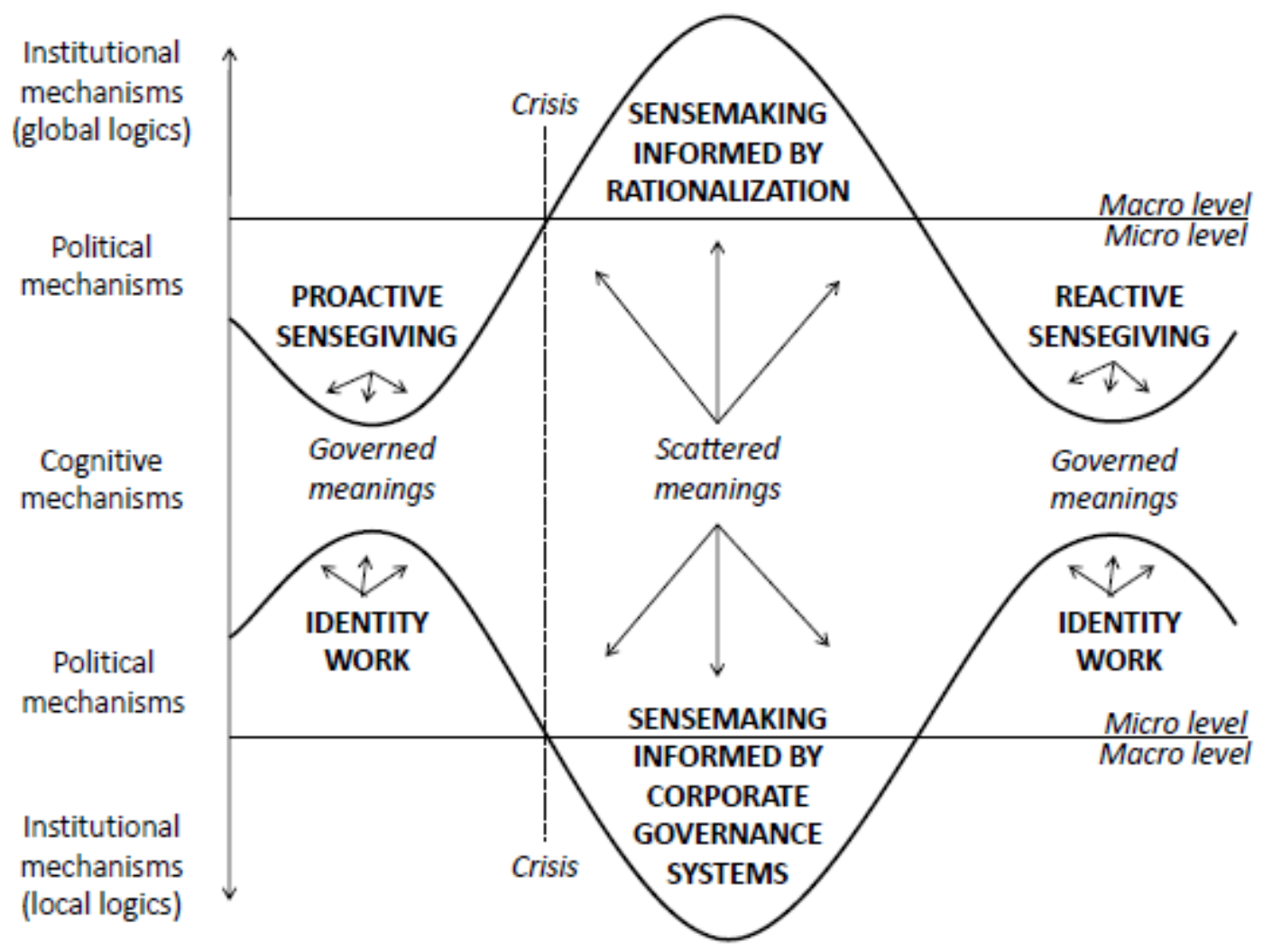

Fig. 4: Centripetal and centrifugal mechanisms in institutional-bound strategic change 


\begin{tabular}{|c|c|c|c|c|c|}
\hline GLOCALIZATION & \multirow[t]{3}{*}{ DESCRIPTION } & \multicolumn{4}{|c|}{ GLOCALIZATION OUTCOMES } \\
\hline & & On strategies & & Horlat st & res \\
\hline & & Local & Global & Local & Global \\
\hline Economic expansion & & & & & \\
\hline Proactive sensegiving & $\begin{array}{l}\text { Propagation of common identity as } \\
\text { "neuronal network": every node is } \\
\text { independent \& interdependent } \\
\text { (polycentric strategic mindset of MNE } \\
\& \text { mandate for the subsidiary as } \\
\text { strategic partner). }\end{array}$ & $\begin{array}{l}\text { Legitimation of local strategic } \\
\text { independence (choice of } \\
\text { product range, addressing } \\
\text { customers, price setting, } \\
\text { competing within network) }\end{array}$ & $\begin{array}{l}\text { Perceived necessity to } \\
\text { compare, coordinate and } \\
\text { negotiate market decisions } \\
\text { and actions }\end{array}$ & $\begin{array}{l}\text { Reproduction of local } \\
\text { organizational identities and } \\
\text { practices: rediscovery/ } \\
\text { reinvention of traditional } \\
\text { identities (prior to } \\
\text { incorporation in multinational } \\
\text { corporate groups) }\end{array}$ & $\begin{array}{l}\text { Consonance among } \\
\text { subsidiary and HQ identities: } \\
\text { network idea vague enough to } \\
\text { be accommodated to local } \\
\text { meanings, but strong enough } \\
\text { to spur global sensemaking }\end{array}$ \\
\hline Sensemaking & $\begin{array}{l}\text { Through encounter and comparison, } \\
\text { identities \& practices become salient } \\
\text { and must be interpreted (in local \& } \\
\text { transnational occasions: committees, } \\
\text { trade fairs, annual meeting) }\end{array}$ & $\begin{array}{l}\text { Instigation of local strategic } \\
\text { reflection: What are our } \\
\text { unique strengths? What do we } \\
\text { risk through the merger? }\end{array}$ & $\begin{array}{l}\text { Common reflection on } \\
\text { strategic synergies: What is } \\
\text { the right level of product } \\
\text { range overlap? }\end{array}$ & $\begin{array}{l}\text { Local reflection: Why do we } \\
\text { do what we do? Why do we } \\
\text { do it in these ways? Are our } \\
\text { practices unique? }\end{array}$ & $\begin{array}{l}\text { Common reflection: What can } \\
\text { we learn from the other } \\
\text { firms? What practices can be } \\
\text { transferred? }\end{array}$ \\
\hline Rationalization (internal) & $\begin{array}{l}\text { Managers espousing corporate } \\
\text { (instead of family or community) } \\
\text { logic require exploiting synergies and } \\
\text { creating specialization }\end{array}$ & $\begin{array}{l}\text { Resistance to rationalization } \\
\text { pressures by affirming local } \\
\text { strategic autonomy }\end{array}$ & $\begin{array}{l}\text { Creation of the idea of the } \\
\text { MNE as a global portfolio of } \\
\text { complementary technologies }\end{array}$ & $\begin{array}{l}\text { Reaffirmation of local } \\
\text { organizational logics but } \\
\text { conceived as mutually } \\
\text { compatible }\end{array}$ & $\begin{array}{l}\text { Emergence of "informal" } \\
\text { divisions to coordinate related } \\
\text { products and customers }\end{array}$ \\
\hline Rationalization (external) & $\begin{array}{l}\text { External actors require product } \\
\text { specialization \& organizational } \\
\text { clarification (sales agents, banks, } \\
\text { consultants) }\end{array}$ & $\begin{array}{l}\text { Concentration on societal } \\
\text { supported product range \& } \\
\text { customer base in answer to } \\
\text { pressures }\end{array}$ & $\begin{array}{l}\text { Definition of product range \& } \\
\text { customer base as result of } \\
\text { network interaction }\end{array}$ & $\begin{array}{l}\text { Affirmation of independence } \\
\text { in the network: practice of } \\
\text { multiple offers to customers } \\
\text { to preserve competitiveness }\end{array}$ & $\begin{array}{l}\text { Internal coordination of offers } \\
\text { in one of the two informal } \\
\text { divisions }\end{array}$ \\
\hline $\begin{array}{l}\text { Identity work } \\
\text { (organizational) }\end{array}$ & $\begin{array}{l}\text { Symbolic and practical actions and } \\
\text { interactions aimed at asserting a } \\
\text { positive identity }\end{array}$ & $\begin{array}{l}\text { Preserving existing pre- } \\
\text { merger company names }\end{array}$ & $\begin{array}{l}\text { Add to local logos common } \\
\text { graphical element }\end{array}$ & $\begin{array}{l}\text { Preservation of societal- } \\
\text { specific organizational } \\
\text { configurations }\end{array}$ & $\begin{array}{l}\text { Selection of local practices as } \\
\text { best practices for all (control, } \\
\text { maintenance, production) }\end{array}$ \\
\hline During crisis & & & & & \\
\hline $\begin{array}{l}\text { Governance mechanisms } \\
\text { and national regulation }\end{array}$ & $\begin{array}{l}\text { Governance types act as divergent } \\
\text { prisms of societal effects; national } \\
\text { regulations restrict available choices } \\
\text { and offer distinct opportunities }\end{array}$ & $\begin{array}{l}\text { Local stakeholders increase } \\
\text { control on strategic decisions: } \\
\text { in F management, in G local } \\
\text { banks, work council, regional } \\
\text { government (Land), in I } \\
\text { owners, in US management }\end{array}$ & $\begin{array}{l}\text { Holding company as last } \\
\text { resort authority struggles in } \\
\text { preserving strategic coherence }\end{array}$ & $\begin{array}{l}\text { Local reorganization } \\
\text { decisions taken according to } \\
\text { local logics with prevailing } \\
\text { divergent or stabilizing } \\
\text { effects }\end{array}$ & $\begin{array}{l}\text { Preservation of network idea } \\
\text { as common identity resource }\end{array}$ \\
\hline Rationalization (internal) & $\begin{array}{l}\text { Formation of multipolar alliance } \\
\text { among some headquarter and local } \\
\text { managers against owners }\end{array}$ & $\begin{array}{l}\text { Owners' resistance in } \\
\text { preserving local strategic } \\
\text { independence }\end{array}$ & $\begin{array}{l}\text { Centrally supported resistance } \\
\text { in preserving the idea of the } \\
\text { MNE as a global portfolio of } \\
\text { complementary resources. }\end{array}$ & $\begin{array}{l}\text { Owners' resistance in } \\
\text { preserving local cultural } \\
\text { specificity of firms }\end{array}$ & $\begin{array}{l}\text { Successful attempt to realize } \\
\text { extensive layoffs in some } \\
\text { locations against owners' } \\
\text { resistance (family mindset) }\end{array}$ \\
\hline Rationalization (external) & $\begin{array}{l}\text { External US restructuring advisor } \\
\text { requires radical divisional } \\
\text { reorganization }\end{array}$ & $\begin{array}{l}\text { Locally supported resistance } \\
\text { to rationalization pressures }\end{array}$ & $\begin{array}{l}\text { Perceived necessity to } \\
\text { increase internal coordination }\end{array}$ & $\begin{array}{l}\text { Centrally supported resistance } \\
\text { in preserving local } \\
\text { organizational logics; } \\
\text { eventually, ceremonial } \\
\text { adoption of divisional form }\end{array}$ & $\begin{array}{l}\text { Centrally supported resistance } \\
\text { in preserving the network } \\
\text { model }\end{array}$ \\
\hline Reactive sensegiving & $\begin{array}{l}\text { Defence of network by compromising } \\
\text { it with meanings derived from the } \\
\text { political pressures and the }\end{array}$ & $\begin{array}{l}\text { Legitimation of local strategic } \\
\text { independence maintained }\end{array}$ & $\begin{array}{l}\text { Cooperation still perceived as } \\
\text { a necessity }\end{array}$ & $\begin{array}{l}\text { Preservation of local } \\
\text { organizational identities and } \\
\text { practices, but uncertainty on }\end{array}$ & $\begin{array}{l}\text { Consonance among } \\
\text { subsidiary and HQ identities } \\
\text { maintained but less clear, due }\end{array}$ \\
\hline
\end{tabular}




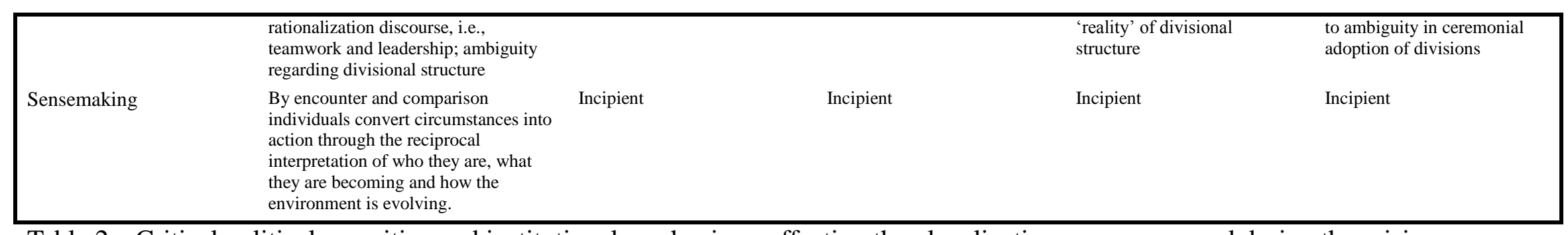

Table 2a: Critical political, cognitive and institutional mechanisms affecting the glocalization process pre and during the crisis

\begin{tabular}{|c|c|c|c|c|}
\hline $\begin{array}{l}\text { GLOCALIZATION } \\
\text { MECHANISMS }\end{array}$ & \multicolumn{4}{|l|}{ QUOTES } \\
\hline \multirow{2}{*}{$\begin{array}{l}\text { Economic } \\
\text { expansion } \\
\text { Sensegiving } \\
\text { (proactive) }\end{array}$} & $\begin{array}{l}\text { On strategies } \\
\text { Local }\end{array}$ & Global & $\begin{array}{l}\text { On organizational structures } \\
\text { Local }\end{array}$ & Global \\
\hline & $\begin{array}{l}\text { Owner-manager: "I agree with [name of } \\
\text { sales manager] that top management } \\
\text { should not be involved in setting rules; the } \\
\text { people in the lines have to be involved in } \\
\text { the creation of value. The companies are } \\
\text { independent" (Plenary discussion at Sales } \\
\text { Meeting 2007) }\end{array}$ & $\begin{array}{l}\text { Owner-manager: "Overlapping [of product } \\
\text { ranges] can be useful, but there should be } \\
\text { fairness. The best in class must take the } \\
\text { orders, maybe compensating the others by } \\
\text { giving away other order to them. Each } \\
\text { company should have } 60 \text { to } 75 \text { percent of } \\
\text { turnover in products for which they are } \\
\text { best in class"; a Top manager sitting in the } \\
\text { first row disapprovingly shakes his head, } \\
\text { meaning that overlapping would be too } \\
\text { much (Sales Meeting 2007) }\end{array}$ & $\begin{array}{l}\text { Owner-manager: "The reason for the } \\
\text { network are the different sites and cultures } \\
\text { of the companies" (Speech at Sales } \\
\text { Meeting October 2007) }\end{array}$ & $\begin{array}{l}\text { An Executive Committee member: "You } \\
\text { ask me what the value added of the HQ is } \\
\text { in this configuration? It is to force people } \\
\text { to benchmark but without forcing". } \\
\text { (October 2007) }\end{array}$ \\
\hline Sensemaking & $\begin{array}{l}\text { A sales manager: "We have a case with a } \\
\text { new project and the client is asking two } \\
\text { companies for an offer. Should we both } \\
\text { put in an offer, given that we are both } \\
\text { technically competent?" (October 2007) }\end{array}$ & $\begin{array}{l}\text { Marketing manager of subsidiary draws } \\
\text { three partially overlapping circles, and } \\
\text { then three non-overlapping circles, as a } \\
\text { metaphor of product ranges of firms, and } \\
\text { advocates for the second solution. } \\
\text { Reaction of a Top manager: "But we need } \\
\text { to maintain competition!" (Group } \\
\text { discussion recorded at Sales Meeting } \\
\text { 2007) }\end{array}$ & $\begin{array}{l}\text { A sales employee talking about a group } \\
\text { creative artistic workshop using clay and } \\
\text { colours to represent the network idea: "As } \\
\text { in the network, the different stages where } \\
\text { not absolutely clear to everybody, when } \\
\text { completed, the purpose was clear and } \\
\text { showed a positive aspect of people } \\
\text { working together with different skills" } \\
\text { (October 2007) }\end{array}$ & $\begin{array}{l}\text { A top manager: "If you do not talk [with } \\
\text { the other sales managers], it means that } \\
\text { you did not understand the network"; } \\
\text { Sales manager: "But it's good to have } \\
\text { competition!"; Top manager: "But only } \\
\text { enough competition to avoid the } \\
\text { competitor enters the market" (Group } \\
\text { discussion recorded at Sales Meeting } \\
\text { 2007) }\end{array}$ \\
\hline $\begin{array}{l}\text { Rationalization } \\
\text { (internal) }\end{array}$ & $\begin{array}{l}\text { A sales employee: "The network should be } \\
\text { a good opportunity for cooperation; } \\
\text { however, since each company is } \\
\text { responsible for its own business and } \\
\text { budget fulfilment, I feel we work under } \\
\text { our synergy possibilities. We achieved } \\
\text { successful cooperation with just a few } \\
\text { companies so far" (October 2007) }\end{array}$ & $\begin{array}{l}\text { A sales employee: "From my point of } \\
\text { view the Network allows working with a } \\
\text { much bigger organization in terms of } \\
\text { sales, marketing, quality, engineering and } \\
\text { also enlarges the possible process (cold } \\
\text { drawing, hot extrusion, hot rolling etc...) } \\
\text { to produce a profile so the Network can } \\
\text { cover a much bigger geographic area, }\end{array}$ & $\begin{array}{l}\text { An Executive Committee member: "There } \\
\text { was a struggle between young people and } \\
\text { [name of the owner-manager]. The young } \\
\text { managers wanted more structure" } \\
\text { (September 2007) }\end{array}$ & $\begin{array}{l}\text { An Executive Committee member: "In the } \\
\text { Executive Committee, we do not have } \\
\text { strictly defined responsibilities, but I am } \\
\text { supposed to be in charge of the "hot } \\
\text { finished product"' (October 2007) }\end{array}$ \\
\hline
\end{tabular}




\begin{tabular}{|c|c|c|c|c|}
\hline & & $\begin{array}{l}\text { increase reactivity and competitiveness, } \\
\text { offering the appropriate product } \\
\text { (technology, price and quality)" } \\
\text { (November 2007) }\end{array}$ & & \\
\hline $\begin{array}{l}\text { Rationalization } \\
\text { (external) }\end{array}$ & $\begin{array}{l}\text { An external sales agent: "For a specific } \\
\text { shape I have received during the years } \\
\text { quotations from Calvi and from Fiav } \\
\text { Mazzacchera. This is confusing" (October } \\
\text { 2007) }\end{array}$ & $\begin{array}{l}\text { An external sales agent: "Today it is not } \\
\text { clear what the strongest points of each } \\
\text { firm are; if I do not know who has the } \\
\text { knowledge and I make a mistake, each } \\
\text { firm should tell me that the other firm of } \\
\text { the network is the best suited for this". } \\
\text { (October 2007) }\end{array}$ & $\begin{array}{l}\text { Owner-manager: "We didn't want to go to } \\
\text { a consultancy like McKinsey. We run } \\
\text { some controlled companies but the } \\
\text { philosophy is not a controlled one. We run } \\
\text { them as a network of independent business } \\
\text { units, as companies that have their own } \\
\text { strategy and organization. ... Consultants } \\
\text { would suggest making central divisions } \\
\text { and transform the factories into units". } \\
\text { (March 2007) }\end{array}$ & $\begin{array}{l}\text { An external sales agent: "Some Calvi } \\
\text { Network decisions (in the range of the hot } \\
\text { extruded profiles companies) for the } \\
\text { clients seem to be determined in advance } \\
\text { within the network companies" } \\
\text { (November 2007) }\end{array}$ \\
\hline $\begin{array}{l}\text { Identity work } \\
\text { (organizational) }\end{array}$ & $\begin{array}{l}\text { Head of communication and Executive } \\
\text { Assistant of one subsidiary: "As you can } \\
\text { see we kept our beautiful red logo. We } \\
\text { added the common symbol but the writing } \\
\text { is the same. Those of Siderval are all } \\
\text { proud that it stayed so" (October 2007). }\end{array}$ & $\begin{array}{l}\text { Director of the company responsible for } \\
\text { marketing and communication activities of } \\
\text { the Group: "Calvi Network Steel Profiles } \\
\text { is now moving from a commercial } \\
\text { solution to a knowledge centre, a place to } \\
\text { spread and share knowledge, through: } 1 \text {. a } \\
\text { newly developed high tech web page, } 2 \text {. } \\
\text { identified colours to distinguish each firm } \\
\text { from the others, 3. the new logo as a } \\
\text { stylized C made up of the different } \\
\text { colours; } 4 \text {. a new advertising campaign: } \\
\text { we never advertised as a network, but now } \\
\text { we will." (October 2007) }\end{array}$ & $\begin{array}{l}\text { Owner-manager: "We had an informal } \\
\text { discussion with the partner of a consulting } \\
\text { firm that was leading us to think of a } \\
\text { divisional type of structure where the } \\
\text { single companies would be factories of the } \\
\text { same divisions leading to more centralized } \\
\text { control. Each company existed before we } \\
\text { purchased them. The growth path of each } \\
\text { company is different and Italian people are } \\
\text { not like the French or German." (March } \\
\text { 2007) }\end{array}$ & $\begin{array}{l}\text { Owner-manager: "We need to collect local } \\
\text { practices as a way to appreciate the culture } \\
\text { of each local reality" (October 2007) }\end{array}$ \\
\hline \multicolumn{5}{|l|}{ During crisis } \\
\hline $\begin{array}{l}\text { Governance } \\
\text { mechanisms and } \\
\text { national } \\
\text { regulation }\end{array}$ & $\begin{array}{l}\text { Owner-manager: "In Germany we have } \\
\text { strong difficulties arising from the fact that } \\
\text { Hoesch's restructuring process has been } \\
\text { conducted by a local advisor who appealed } \\
\text { to all the stakeholders of the company, } \\
\text { which is part of the local environment for } \\
\text { over } 200 \text { years. The Group has been } \\
\text { divested of ownership on certain } \\
\text { decisions, being reduced to a mere } \\
\text { shareholder." (July 2011) }\end{array}$ & $\begin{array}{l}\text { Owner-manager: "It is necessary to } \\
\text { reaffirm the role of the Holding company } \\
\text { in determining the strategy" (July 2011) }\end{array}$ & $\begin{array}{l}2009 \text { Consolidated Financial Statement: } \\
\text { [concerning the US subsidiary firm] "The } \\
\text { workforce reduction was prescribed by the } \\
\text { decrease of activity. For most of the year } \\
\text { the } 32 \text { hours working week has been } \\
\text { adopted and the department managers' } \\
\text { salary has been reduced by } 20 \% \text {. } \\
\text { Regarding employees, the number of } \\
\text { working hours per week remained } \\
\text { unchanged at } 40 \text { but the salary has been } \\
\text { reduced by } 10 \% \text {." [concerning one of the } \\
\text { Italian subsidiary-firm] "In January the } \\
\text { mobility procedure started, which based } \\
\text { on the trade union agreement and on the } \\
\text { voluntary accession of workers, should } \\
\text { lead to an overall personnel reduction by } \\
11 \text { people by } 31 / 12 / 2010 \text {. This action will } \\
\text { affect only employees who would have } \\
\text { completed the requirements for retirement } \\
\text { in the next three years." }\end{array}$ & $\begin{array}{l}\text { Owner-manager: "I'm increasingly } \\
\text { convinced that the model we tried to } \\
\text { structure is effective in the management of } \\
\text { a crisis situation, provided that we do not } \\
\text { forget to be part of a Network able to } \\
\text { create synergies" (July 2011) }\end{array}$ \\
\hline Rationalization & A top manager on the role of the Group & A top manager: "During crisis situations & A top manager: "If it gets difficult, we & Owner-manager: "Some managers have \\
\hline
\end{tabular}




\begin{tabular}{|c|c|c|c|c|}
\hline (internal) & $\begin{array}{l}\text { controller: "We must define common } \\
\text { timings for all the subsidiary-firms". } \\
\text { Owner-manager: "No. Rhythm and timing } \\
\text { are driven by the needs of individual } \\
\text { companies. The only constraint should be } \\
\text { represented by the date of the Holding } \\
\text { company Board of Director" (July 2011) }\end{array}$ & $\begin{array}{l}\text { we tend to reactions such as 'Every man } \\
\text { for himself'. Being part of a Group, } \\
\text { instead, helps to mobilize the right } \\
\text { resources" (July 2011) }\end{array}$ & $\begin{array}{l}\text { would have to cut a branch to save the } \\
\text { tree"; An Owner: "You cannot eradicate a } \\
\text { family member! Would you?" (October } \\
\text { 2008) }\end{array}$ & $\begin{array}{l}\text { found an agreement to sabotage [my idea } \\
\text { not to dismiss anyone]!" (September } \\
2010 \text { ) }\end{array}$ \\
\hline $\begin{array}{l}\text { Rationalization } \\
\text { (external) }\end{array}$ & $\begin{array}{l}\text { A CEO of the German subsidiary talking } \\
\text { to the advisors: "If you want this model to } \\
\text { work we have to find the right way to } \\
\text { include the German subsidiary. We } \\
\text { definitely have to find the right } \\
\text { communication and reporting tools, } \\
\text { otherwise it will be problematic." (July } \\
\text { 2011) }\end{array}$ & $\begin{array}{l}\text { Owner-manager, reporting what was said } \\
\text { by the advisors in a previous formal } \\
\text { meeting: "It is necessary to fill the lack of } \\
\text { collaboration and coordination. In the } \\
\text { years before the crisis, they weren't } \\
\text { required, since we were all blinded by } \\
\text { abundance" (July 2011) }\end{array}$ & $\begin{array}{l}\text { Owner-manager: "[name of the US } \\
\text { restructuring advisor] submitted an } \\
\text { abstract organization chart. Now we have } \\
\text { to dress it up" (July 2011) }\end{array}$ & $\begin{array}{l}\text { Owner-manager: "We reached a } \\
\text { compromise with the US advisor and the } \\
\text { Banks in order to preserve the possibility } \\
\text { of maintaining a network model" (July } \\
\text { 2011) }\end{array}$ \\
\hline $\begin{array}{l}\text { Sensegiving } \\
\text { (reactive) }\end{array}$ & $\begin{array}{l}\text { Owner-manager: "We have to think of our } \\
\text { future and we need to be sure that our } \\
\text { business model that speaks about } \\
\text { independency of the companies and about } \\
\text { each company defining its strategy to fulfil } \\
\text { the mission that is given by the group, but } \\
\text { using synergies, we have to see if this } \\
\text { model/how this model can be sustained" } \\
\text { (Speech recorded during the presentation } \\
\text { of the new organizational and commercial } \\
\text { structure - July 2011) }\end{array}$ & $\begin{array}{l}\text { Owner-manager: "We need to define and } \\
\text { rationalize all the practices, all the habits, } \\
\text { all the ways of running the everyday } \\
\text { business, in a way that we can really be } \\
\text { sure that synergies are created and } \\
\text { synergies are developed on the technical, } \\
\text { production and commercial side." (Speech } \\
\text { recorded during the presentation of the } \\
\text { new organizational and commercial } \\
\text { structure - July 2011) }\end{array}$ & $\begin{array}{l}\text { Owner-manager: "We also have to } \\
\text { consider that our German company HSP is } \\
\text { ruled by a legal way of governance which } \\
\text { is called Mitbestimmung which more or } \\
\text { less means employee participation in the } \\
\text { governance of the company. Every } \\
\text { decision and every change in the } \\
\text { organizational model of the company for } \\
\text { the future has to be taken in accordance } \\
\text { with these rules. This is a further } \\
\text { complication for our process of change in } \\
\text { our organizational model." (Speech } \\
\text { recorded during the presentation of the } \\
\text { new organizational and commercial } \\
\text { structure - July 2011) }\end{array}$ & $\begin{array}{l}\text { Owner-manager: "It's really an } \\
\text { organizational change where each person } \\
\text { should be brought to redefine his activity } \\
\text { and job in a more synergistic approach, } \\
\text { this is very important because in my view, } \\
\text { independency of each activity is a very } \\
\text { strong statement for the holding company, } \\
\text { but given the changes that were brought } \\
\text { by the economical crisis, given the } \\
\text { difficult situation the group found itself in, } \\
\text { the only way to quickly abandon this } \\
\text { difficult position and the only way to take } \\
\text { advantages of the multiple opportunities } \\
\text { that the crisis is also bringing, is to work } \\
\text { on synergies. And, synergies have to be } \\
\text { really our main thought for the following } \\
\text { months." (Speech recorded during the } \\
\text { presentation of the new organizational and } \\
\text { commercial structure - July 2011) }\end{array}$ \\
\hline Sensemaking & \multicolumn{4}{|c|}{ Owner-manager: "Never stop asking oneself 'What does working in a network mean?"' (July 2011) } \\
\hline
\end{tabular}

Table 2b: Representative supporting empirical data for glocalization mechanisms (some quotes translated from French, German or Italian) 